\title{
THE PALAEO-DRAINAGE OF THE LA PLATA RIVER IN SOUTHERN BRAZIL CONTINENTAL SHELF
}

\author{
Iran Carlos Stalliviere Corrêa ${ }^{1}$, Svetlana Medeanic ${ }^{2}$, Jair Weschenfelder ${ }^{1}$, \\ Eliŕro Ernestino Toldo Júnior ${ }^{1}$, José Carlos Nunes ${ }^{1}$ and Ricardo Baitelli ${ }^{1}$
}

\begin{abstract}
This paper addresses the characterization of the geomorphology and palaeo-evolution of the La Plata River on the south Brazilian continental shelf, through bathymetric data and sedimentary and palynological analysis from sediment core samples. The analysis allowed us to characterize a transgressive depositional sequence in the La Plata River palaeo-channel. The palynological sequences revealed continental fresh water environments, that involved into lagoonal and mixohaline environments and then into shallow marine environments towards the top, thus characterizing a fluvial-estuarine environment. These new data offer sufficient information to establish the palaeo-geographic evolution of the La Plata River palaeo-channel and its local influence on the sedimentation of the Rio Grande do Sul State continental shelf.
\end{abstract}

Keywords: palaeo-valley, continental shelf, marine transgression, La Plata River.

RESUMO. 0 presente trabalho trata da evolução e caracterização geomorfológica do paleocanal do rio de La Plata sobre a plataforma continental sul-brasileira. A partir da análise de dados de levantamento batimétrico e da obtenção de testemunhos no paleocanal, coletados para fins de estudo morfológico, sedimentológico e palinológico, foi possível identificar sequências deposicionais transgressivas. Os registros palinológicos evidenciaram ambientes com influência continental de água doce, migrando para lagunar, mixohalino e marinho raso, em direção ao topo dos testemunhos, caracterizando um ambiente fluvio-estuarino. Os resultados obtidos contribuem para o estabelecimento da evolução paleogeográfica e da influência do paleocanal do rio de La Plata na sedimentação, de parte, da plataforma continental do Rio Grande do Sul.

Palavras-chave: paleovale, plataforma continental, transgressão marinha, rio de La Plata.

\footnotetext{
${ }^{1}$ Centro de Estudos de Geologia Costeira e Oceânica - CECO, Instituto de Geociências - UFRGS, Av. Bento Gonçalves, 9500, Prédio 43125, Caixa Postal 15.001, Bairro Agronomia, 91501-970 Porto Alegre, RS, Brazil. Phone: +55(51) 3308-9855; Fax: +55(51) 3308-7302 - E-mails: iran.correa@ufrgs.br; jair.weschenfelder@ufrgs.br; toldo@ufrgs.br; jose.nunes@ufrgs.br; baitelli@ufrgs.br

2 Instituto de Oceanografia - FURG (in memoriam)
} 


\section{INTRODUCTION}

Previous works carried out on the south Brazilian continental margin have described a series of depositional environments, either related to sediment deposition during the Latest PleistoceneHolocene transgression, or related to depositional sequences linked to the previous late Pleistocene regression (Martins et al., 2005). In such a context, geomorphological features, such as fluvial channels are preserved on the subsurface of continental shelves related to sea-level variations during the Quaternary (Conti, 2009).

Nonetheless, aside from variations in the sedimentary $d y-$ namic that may lead to base level oscillations capable of causing changes in the sedimentary regime, and quite often associated displacement of river beds, tectonic events may exert a dominant control in channels orientation and migration, and even causing its structural entrenchment.

Besides that, several studies have also revealed that the geometry of palaeo-drainages on continental shelves is not necessarily related to the location of current active fluvial systems. This geomorphological mismatch raises a series of questions to establish the relationship between the drainage network, the hydrological regime and the evolution of the morphological features of continental shelves (Chiocci, 2001; Figueiredo \& Madureira, 2004; Abreu \& Calliari, 2005; Lobo et al., 2006; Conti, 2009).

According to Corrêa (1986) and Urien \& Martins (1989), sealevel position during the last glacial maximum was at around $-120 \mathrm{~m}$ on the south Brazilian continental shelf, representing thus the starting depth for the last major latest PleistoceneHolocene transgression.

The stratigraphic succession of the southern Brazilian continental margin evidence a series of features indicative of sealevel oscillations, since the opening the Atlantic Ocean. Asmus (1981) identified numerous features on seismic lines, like palaeoshelves and palaeo-deltas, related to shoreline migration in transgressive-regressive trends.

During the last late Pleistocene regression, when the sea-level reached its lowest level ( $-120 \mathrm{~m}$ below present sea-level; Corrêa, 1986 and 1990), the continental shelf was converted into an extensive coastal plain, with the presence of countless fluvial systems, whose drainages affected the edge of the shelf, giving rise to a series of associated deltaic complexes and submarine canyons, feeding sedimentary prisms on the continental slope and rise, such as the Rio Grande Cone (Martins, 1984).

Later on the sea-level began to rise, leading to the flooding of the fluvial systems and forming estuaries, deltas and other transitional environments, leaving a transgressive surface, and promoting sediments reworking.
Kowsmann et al. (1977) described the presence of a palaeochannel parallel to the coast of Rio Grande de Sul, partially filledin, and extending up to the Southern region of Uruguay. These authors described this feature as a palaeo-channel previously connected to La Plata River. Urien (1970), Urien \& Martins (1974) and Urien \& Ewing (1974) also attributed this feature to a previous South-North course of the La Plata River, which had a significant role to deliver sediments to the continental slope and rise. According to Corrêa (1987a, 1987b, 1990); Laborde (1999); Corrêa et al. (1996), the central La Plata palaeo-channel is infilled by a basal sand deposit, covered by mud and overtopped with sands. Several authors ascribe an Uppermost Pleistocene-Holocene age for the palaeo-channel infilling, related to deposition that occurred during the last transgression (Kowsmann \& Costa, 1979; Corrêa, 1987a; Martins et al., 2003). However, Ayup-Zouain (1987) suggests that the surface muddy deposit is a result of the present transport and deposition of fine sediments from the La Plata River through turbidity currents that move along the palaeo-channel.

Morpho-structural analysis carried out in the area by Corrêa $(1990,1996)$ allowed the recognition of an elongated negative morpho-structural anomaly following a coast-parallel axis located between Sarita Lighthouse and Chuí. Alongside positive lateral morpho-structural anomalies were also described. This configuration of morpho-structural anomalies was interpreted to reflect a central graben (negative anomaly) shouldered by lateral horsts (positive anomalies), coincident with the orientation of the La Plata palaeo-channel.

More recently, Campos et al. (2009) described several hydroacoustic profiles indicating that the palaeo-channel of the La Plata River displays a gradational increase of up to $30 \mathrm{~m}$ in local depth, in relation to the adjacent external shoulders.

Reconstruction of palaeo-sedimentary environments may be attained through analyses of the palaeontological content of sedimentary sequences obtained from sediment cores and wells. Among different kinds of microfossils, palynomorphs stand as a key tool for palaeo-reconstruction of the coastal zones. The diversity of palynomorphs in the quaternary sediments of the coastal zones is highly variable, but the occurrence of certain taxons of palynomorphs can be used as indicative of sedimentary palaeoenvironments (Medeanic \& Corrêa, 2007, 2010; Medeanic et al., 2009a, 2009b).

\section{STUDY AREA}

The study area encompasses the palaeo-channel segment of the La Plata River which is located on the continental shelf of Rio 


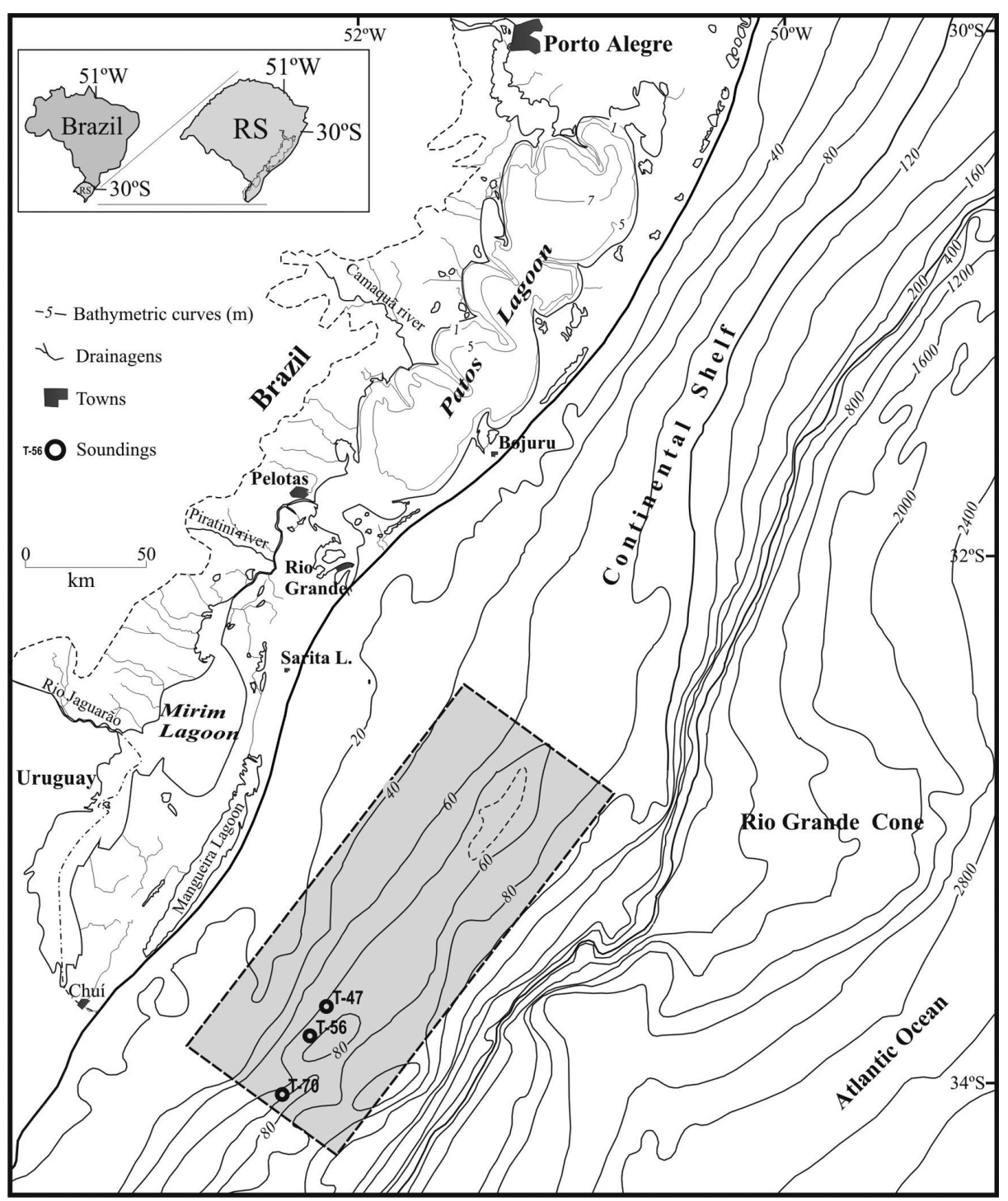

Figure 1 - Bathymetric map and location of the study area.

Grande do Sul and part of the Uruguayan continental shelf, between $32^{\circ} 40^{\prime} \mathrm{S}$ and $34^{\circ} 20^{\prime} \mathrm{S}$ latitudes and $51^{\circ} \mathrm{W}$ and $53^{\circ} \mathrm{W}$ longitudes (Fig. 1).

The La Plata palaeo-channel encompasses an area of about $3,500 \mathrm{~km}^{2}$, extending from the La Plata estuary, in the Southern region of Uruguay, as far as the Sarita lighthouse, on the coast of Rio Grande de Sul (Brazil).

The continental shelf of Rio Grande do Sul displays a maximum width of $200 \mathrm{~km}$, in the Northern part of the studied area, close to the Sarita lighthouse, whereas in the most southerly part, the shelf narrows down to around $150 \mathrm{~km}$ wide. The maximum depth of the channel is around $-80 \mathrm{~m}$, displaying a declivity from Southeast to Northwest.

\section{MATERIAL AND METHODS}

The morphology of the Southern continental shelf of Rio Grande do Sul was obtained through the construction of a Bathymetric Digital Model (BDM). Depth measurements used for elaborating the BDM were obtained at the Brazilian Navy bathymetric sounding charts, available at $\mathrm{CHM}$ - Centro Hidrográfico da Marinha do Brasil (The Hydrographic Center of the Brazilian Navy). Bathymetric sounding charts data were digitized and processed, to generate a regular grid, with cells of $100 \times 100 \mathrm{~m}$. Ecobathymetric profiles acquired during Oceanographic Operation GEOMAR VII were digitized and geo-referenced, providing extra data for the elaboration of the BDM and thus for the delimitation of the La Plata palaeo-channel. 
GEOMAR VII piston core sedimentary samples, as well as surface samples collected with Van Veen and Dietz Lafond were also available for this study. Processing and sedimentological analyses of sediment samples were conducted at CECO/UFRGS Sedimentology Laboratory, following the standard classification of Folk \& Ward (1957).

Thirty (30) samples were collected from cores T-47, T-56 and T-70, obtained during the Oceanographic Operation GEOMAR VII for the palynological analyses. The sampling intervals were spaced from 10 to $60 \mathrm{~cm}$, preferably on muddy sediment intervals. Chemical treatment of the samples was conducted according to the usual techniques described by Faegri \& Iversen (1975). The samples, $50 \mathrm{~g}$ each one, were chemically treated with $\mathrm{HCl}(10 \%)$ and $\mathrm{KOH}(10 \%)$, before the separation of inorganic and organic substances through dense liquids (aqueous solution of $\mathrm{ZnCl}_{2}$ with a density of $2.2 \mathrm{~g} / \mathrm{cm}^{3}$ ). To preserve the opal phytoliths, spicules of sponges and diatom frustules, the samples were not treated with HF. Sediment and microfossil thinsections were archived at the palynology museum at the Center for Studies of Oceanic and Coastal Geology (CECO) at the UFRGS Institute of Geosciences. Palynological analysis made use of a Lobomed-400 transmitted light biological microscope with magnifying power of $500 \times$. The identification of pollens from vascular plants was based on the reference collection of pollens from present-day plants. Palynomorphs of algae and fungi were recognized based on the literature (e.g., van Geel, 1976; van Geel \& van der Hammen, 1978; Jarzen \& Elsik, 1986; Brasier, 1992; Jankocská \& Komárek, 2000; Cordazzo \& Stürmer, 2007). The microforaminifera fauna (palynoforaminifera) was identified based on the works of Van Veen (1957) and Pantic \& Bajraktarevic (1988). To characterize the general state of the organic matter found on the palynological thin-sections, the works of Batten (1996) and Tyson (1995) were used. The identifications, albeit approximate, of the phytoliths belonging to the monocotyledon plants were based on the pioneering works by Medeanic et al. (2008 and 2009b) on phytoliths of present-day plants from the coastal plains of Rio Grande do Sul.

\section{BATHYMETRIC DIGITAL MODEL}

The general analysis of the morphological features of the area was possible through preparation of the Bathymetric Digital Model (BDM).

The initial work consisted of tracing the bathymetric chart of the study area. The scale chosen was 1:265,000, as this was the one best scale adapted to the outline of the isobathymetric curves spaced every $2 \mathrm{~m}$. The outline of the isobaths ranged from the coastline to a depth of $100 \mathrm{~m}$. For detailing the bathymetric map, data from the Brazilian Navy bathymetric sounding charts were used, along with ecobathymetric profiles of the studied region, obtained during the Oceanographic Operation GEOMAR VII.

Based on the detailed bathymetric sounding chart, 23 bathymetric profiles were traced, spaced by $5.3 \mathrm{~km}$, covering mainly the area encompassing the palaeo-channel and its surroundings, seeking to have a better visualization of the bottom morphology.

Corrêa (1990 and 1996) described the presence of a palaeochannel based on bathymetric data. On bathymetric profiles we observe the presence of a clearly-marked terrace at $-60 / 70 \mathrm{~m}$. This palaeo-depth was attained at circa 11,000 years BP, during the last marine transgression, and this terrace was interpreted as the stabilization of sea-level during the transgression, when part of the La Plata palaeo-channel was progressively filled up.

The Bathymetric Digital Model (Fig. 2) shows a homogeneous continental shelf with a smooth slope. On the inner continental shelf, smooth isobaths are locally irregular probably due to the presence of bioclastic sand banks, while on the outer shelf we observe the presence of the La Plata palaeo-channel, formed during sea-level lowstand. To the southeast the palaeo-channel is limited by a bathymetric high responsible for its direction.

The characterization of this palaeo-channel is perfectly identifiable in the ecobathymetric profiles perpendicular to the coastline, as can be seen in Figure 3.

Figure 4 shows the bathymetric profiles obtained from the detailed bathymetric map drawn up for preparation of the BDM. Analyzing the bathymetric profiles obtained, we note the presence of the palaeo-channel of the La Plata River well outlined over the three profiles. Profile 3, located in the most southerly part of the area, shows the palaeo-channel in a U shape, coinciding with the ecobathymetric record presented in Figure 3. The depth observed is approximately $70 \mathrm{~m}$. In the two other profiles (profile 2 and profile 1), the channel appears smoother, probably due to the natural declivity of the channel and the progressive infilling that occurred during the transgressive period. The depth observed is approximately $58 \mathrm{~m}$.

\section{INDICATIONS OF A SEA-LEVEL LOWSTAND}

The cores described in this work (T-70, T-56 and T-47) (Figs. 5, 6 and 7 ) display sedimentary units that include remains of fauna and different types of palynomorphs which characterize the passage of a continental environment to a mixohaline and even shallow marine environments. 


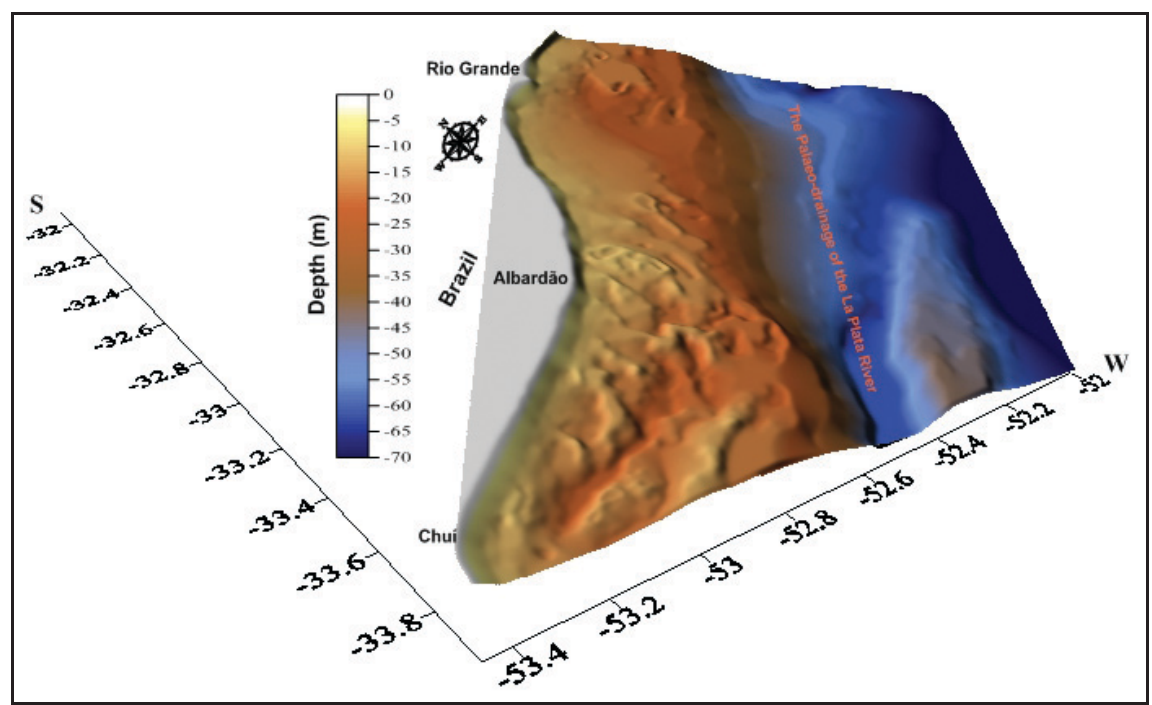

Figure 2 - Bathymetric Digital Model of the Southern continental shelf showing the palaeo-channel of the La Plata River.

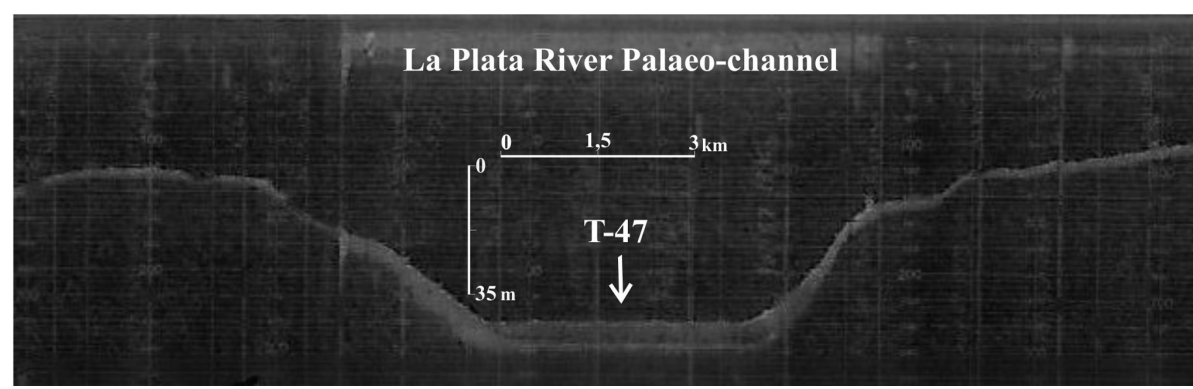

Figure 3 - Ecobathymetric record of the palaeo-channel of the La Plata River and location of cores used in this study.

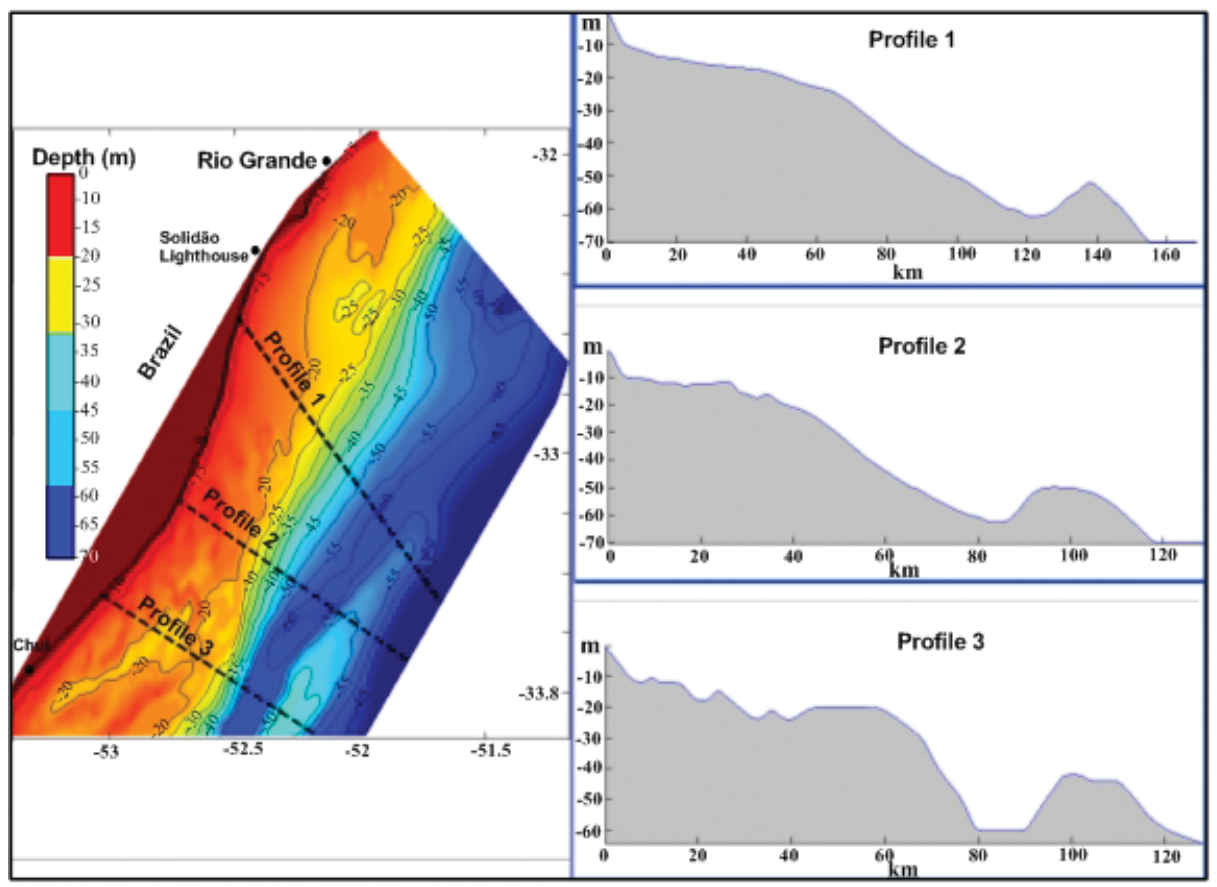

Figure 4 - Bathymetric profiles depicting the palaeo-channel of the La Plata River. 


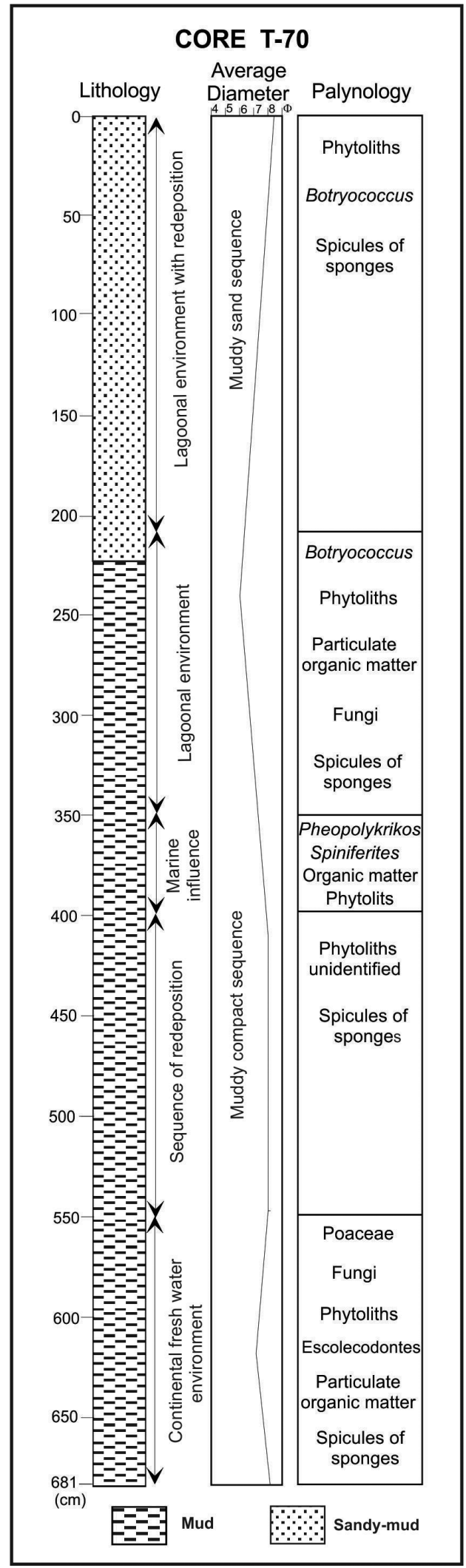

Figure $\mathbf{5}$ - Description of core T-70 from the palaeo-channel of the La Plata River.

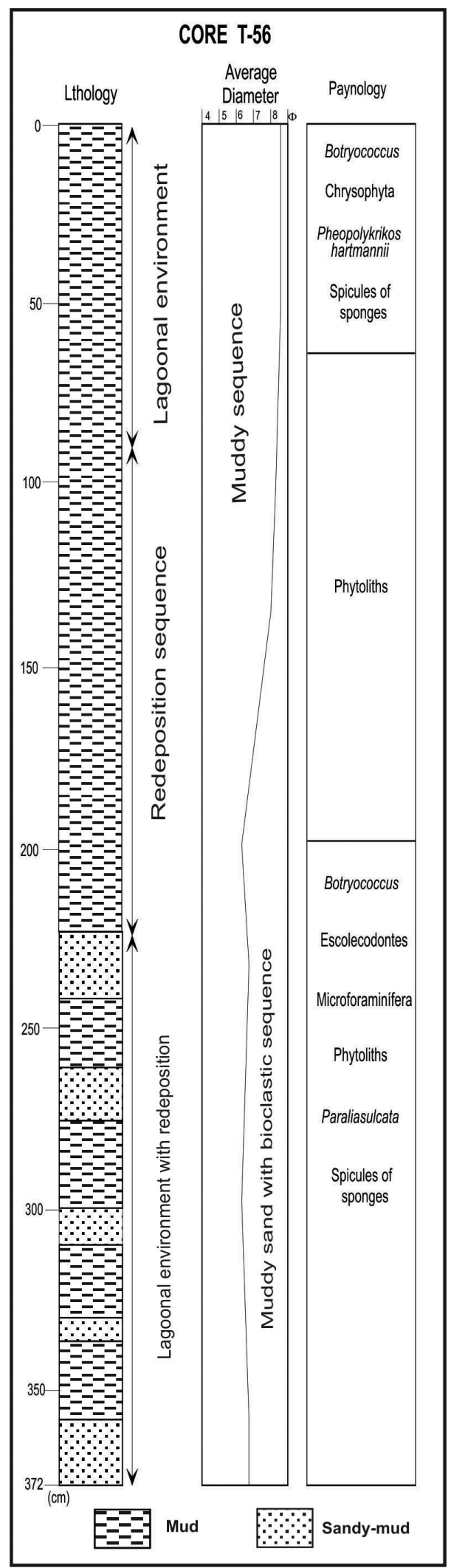

Figure $\mathbf{6}$ - Description of core T-56 from the palaeo-channel of the La Plata River. 


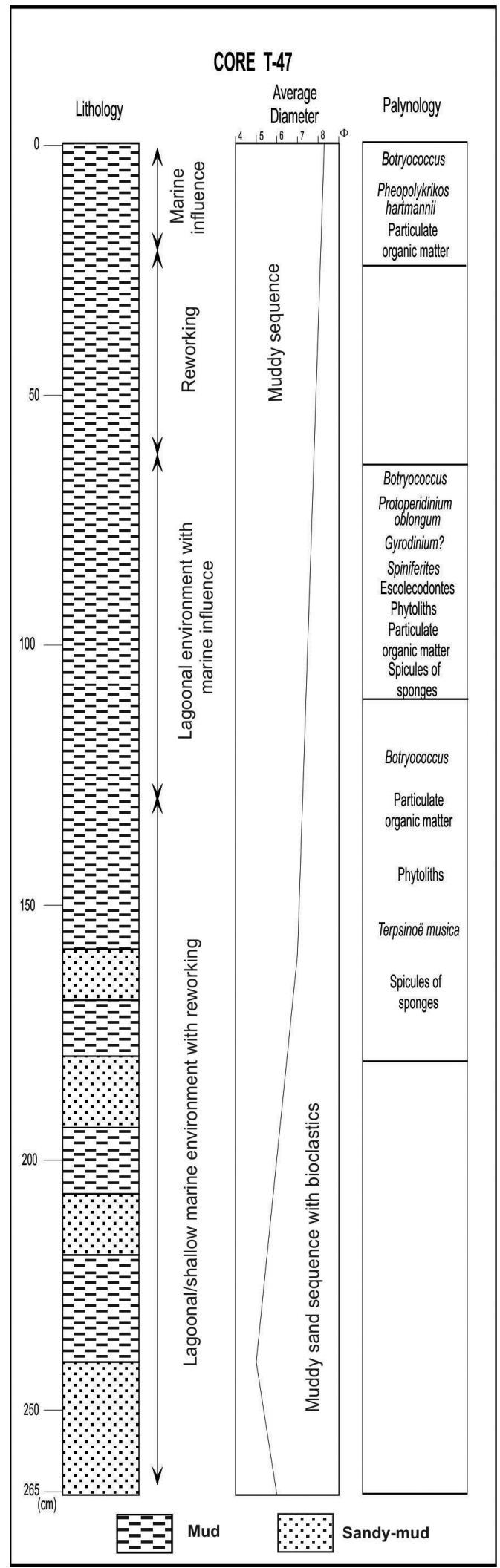

Figure 7 - Description of core T-47 from the palaeo-channel of the La Plata River.
Cores T-56 and T-47 display basal muddy levels interbedded with sandy units which characterize the hydrodynamic variations of the environment. These may be considered sediments deposited in an estuarine regime or even a fluvial channel.

The palaeo-channel belonging to the palaeo-drainage of the La Plata River was one responsible for transporting sediments that contributed to the formation of the sedimentary deposits of the Rio Grande Cone.

\section{Description of the Cores \\ Core T-70 - GEOMAR VII}

Depth: 65 m / Length: $6.81 \mathrm{~m}$

The sedimentary succession is formed, from the base up to $2.10 \mathrm{~m}$, by compact mud interbedded with fluid mud layers. This muddy unit grades gradually upward (between $2.10 \mathrm{~m}$ to $1.10 \mathrm{~m}$ ) into an homogeneous sandy-mud layer, which grades itself into a less sandy-mud up to the top of the core.

Bertels et al. (1984) studied the fauna of this core and observed, from the base up to the level $2.10 \mathrm{~m}$, an alternation of azoic levels with poor microfauna. The upper level, from $2.10 \mathrm{~m}$ to $0.20 \mathrm{~m}$, displays an impoverishment of fauna, with a reduction in the size of the carapaces, probably due to the introduction of continental sediments. From $0.2 \mathrm{~m}$ to the top marine muds predominate.

The palynological studies recorded the occurrence of various palynomorphs. Besides palynomporphs scarce frustules of diatoms and spicules of sponges were found. The base $(6.81 \mathrm{~m}$ to $5.50 \mathrm{~m}$ ) of the core displays pollens of angiosperm, mainly belonging to the herbaceous plants of the families Cyperaceae, Poeceae, Polygalaceae and Scrophulariceae. It also displays the spores of pteridophyta of the Azollafiliculoides, Alsophyla, Ophioglossum and Osmunda species. Spores of bryophyta are represented by Phaeoceros. At the base of the core were found oogonia of charophyta belonging to the Chara genus, which are found in fresh water environments. Various escolecodontes were found. Palynomorphs of fungi are often present. Microfossils with a siliceous composition are highly variable, represented by frustules of diatoms, spicules of sponges and phytoliths. The rare, poorly-preserved diatoms were not identified. We note the presence of particulate and amorphous organic matter. The association of these palynomoprhs characterizes a fresh water continental environment.

The upper unit between $5.50 \mathrm{~m}$ and $4.00 \mathrm{~m}$ is poor in palynomorphs, showing only amorphous organic matter, rare phytoliths and some spicules of sponges, poorly preserved. This unit may be characterized as a unit that underwent erosion and redeposition of sediments. 
The unit between $4.00 \mathrm{~m}$ and $3.50 \mathrm{~m}$ is characterized by the presence of spores of bryophytes of the Anthoceros and Phaeoceros species. Cysts of marine dinoflagellates are represented by the species of Pheopolykrikos and Spiniferites, besides particulate organic matter and some phytoliths. This unit may be interpreted as of marine/estuarine influence.

The unit between $3.50 \mathrm{~m}$ and $2.15 \mathrm{~m}$ displays dominant palynomorphs of chlorophylls represented by colonies of BotryococCUS, and also the dominant presence of phytoliths and particulate organic matter throughout the entire unit. In a lesser proportion we note the presence of prasinopheceae, palynomorphs of fungi and spicules of sponges at the base of the unit. In the top portion of the unit there is a predominance of pollens of herbaceous plants, mainly mesophylls and hydrophylls - Cypereceae, Polygonum hydropipereroides and Typha. The spores of aquatic plants are represented by Azollafiliculoides. Other spores beIonging to pteridophyta mainly from humid regions are: Blechnum, Huperzia, Lycopodiella, Microgranna, Osmunda and Polypodiceae, with predominance in the upper part of the unit. Among the bryophytes we have the Phaeoceros species. Palynomorphs of chorophylls are represented mainly by the colonies of Botryococcus. From the presence of colonies of Botryococcus, frequently recorded in the surface sediments of the Patos lagoon (Medeanic et al., 2007), pollens and spores of periphytic aquatic plants, the unit may be characterized as a lagoonal/estuarine environment.

The top unit, $2.15 \mathrm{~m}$ to $0.20 \mathrm{~m}$, is very poor in palynomorphs, with predominance of phytoliths, amorphous organic matter, colonies of Botryococcus, spicules of sponges and bryophytes of Phaeoceros. At some levels we find spores of the aquatic pteridophyta Azollafiliculoides. The diatoms of the species Navicula, Terpsinoë musica and Paraliasulcata are present. The former corresponds, respectively, to fresh water environment, and the other two to brackish water. Relatively frequent, but fragmented and poorly preserved, we find spicules of sponges and phytoliths of monocotiledonea herbaceous plants. Organic matter is found more frequently as amorphous and rarely as particulate. This unit may be characterized as a lagoonal/estuarine environment with continental input. From $0.20 \mathrm{~m}$ to the top of the core, the sedimentary unit is composed of marine muds.

\section{Core T-56 - GEOMAR VII}

\section{Depth: 74 m / Length: $3.72 \mathrm{~m}$}

The base of core ( $3.73 \mathrm{~m}$ to $2.30 \mathrm{~m}$ ) is composed by muddy sediments interbedded with levels of muddy sand. From $2.30 \mathrm{~m}$ to $1.90 \mathrm{~m}$ sandy-mud grades into a homogeneous mud towards the top. There is a decreasing variation in the average grain size of particles from the base to the top, ranging from medium silt to clay.

Rodrigues \& Carvalho (1980) studied samples from a core close to this one, in which they observed that the benthonic foraminifera increased in number and species from the base to the top, whereas planktonic foraminifera were absent. This distribution may be linked to the final phase of a transgressive cycle.

The palynological analysis showed that from the base up to $2.20 \mathrm{~m}$ of this core palynomorphs of chlorophyll predominate, represented by colonies of Botryococcus followed by Spirogyra, with an increase of the former towards the top of the unit. At the very base of the unit we observe the presence of prasinophyceae of Leiosphaeridae and some examples of palynoforaminifera. The escolecodontes of microforaminifera, phytoliths and spicules of sponges (Spongi) seem to diminish from the base up to the level $2.30 \mathrm{~m}$, while the diatoms of the species Diploneous, Paraliasulcata and Stauroneus increase slightly. The presence of fresh water palynomorphs of chlorophylls and phytoliths, and also of palynomoprhs or palynoforaminifera and prasinophyceae, which are marine indicators, characterizes the interval described as belonging to a fluvial/lagoonal environment.

In the interval from $2.30 \mathrm{~m}$ to $0.90 \mathrm{~m}$ occur amorphous organic matter and phytoliths, characterizing reworking and redeposition of material in an estuarine environment.

The interval from $0.90 \mathrm{~m}$ to the top of the core displays palynomorphs of Chlorophyta represented by the predominant occurrence of colonies of Botryococcus, followed by Dinophyte (Pheopolykrikoshartmannii), prasionphyceae of Leiosphaeridia and spicules of sponges. Particulate and amorphous organic matter is rare. The presence of fresh water palynomorphs of Chlorophyta and marine palynomorphs suggests a lagoonal/estuarine environment and rare frequency and poor preservation indicate reworking and re-deposition of sediments.

\section{Core T-47 - GEOMAR VII}

Depth: 78 m / Length: 2.65 m

This core displays a basal unit ( $2.65 \mathrm{~m}$ to $1.60 \mathrm{~m}$ ) formed by sandy-mud interbedded with levels with higher sand content. The top unit $(1.60 \mathrm{~m}$ to $0 \mathrm{~m}$ ) is a plastic mud. We note a concentration of estuarine/marine biodetritus, between $1.60 / 1.70 \mathrm{~m}$; 1.80/1.90 m; 2.10/2.22 m; and 2.40/2.65 m. There is a sediment grain size reduction, from base to top, from medium silt to clay.

The palynological description, from the base of the core up to $1.30 \mathrm{~m}$, denotes the presence of colonies of Botryococcus. The relatively scarce organic matter is found as particulate form. Siliceous microfossils are represented by phytoliths of herbaceous plants, broken spicules of sponges and rare frustules of 
diatoms of the species Coscinodiscus and Terpsinoë musica. This unit is interpreted as a lagoonal/estuarine or shallow marine environment with reworked material.

The interval from $1.30 \mathrm{~m}$ to 0.60 shows the predominant occurrence of palynomorphs of colonies of Botryococcus followed by cysts of marine dinoflagellates of the species Protoperidiniumoblongum, Gyrodinium and Spiniferites, as well as escolecodontes, particulate organic matter, phytoliths and spicules of sponges. A mixture of palynomorphs of algae of a lagoonal environment (Botryococcus) and cysts of marine dinoflagellates, plus the presence of escolecodontes, phytoliths and particulate organic matter characterize the sequence as a lagoonal/estuarine environment with greater marine influence.

In the interval from $0.60 \mathrm{~m}$ to $0.20 \mathrm{~m}$ palynomorphs were absent suggesting sedimentary reworking during the last marine transgression.

The interval from $0.20 \mathrm{~m}$ to the top indicates a marine influence, displaying colonies of Botryococcus, cysts of dinoflagellates of the species Procentrumgracile and Pheopolykrikoshartmannii and scarce amorphous organic matter.

\section{INFLUENCE OF THE LA PLATA RIVER ON THE CONTINENTAL SHELF}

Tomazelli (1978) and Corrêa (1987a) observed on the continental shelf of Rio Grande do Sul a dominant occurrence of augitehypersthene minerals in the mineralogical assemblage of heavy minerals of the La Plata palaeo-channel and adjacent area. This mineralogical assemblage supports the hypothesis of a close relationship between these sediments and the La Plata sediments, as these minerals are common in the continental rocks of the pampas.

Martins (1978) studying inland mud pits, classified this same heavy minerals assemblage as distal Platina sedimentary facies, linking it to the palaeo-drainage of the La Plata River in the Pleistocene, when the sea-level was below its current level. As well as that, Martins et al. (2003) classified the sedimentary package of the palaeo-channel as relict muds from the La Plata River discharge, during sea-level lowstands, prior to the last deglaciation.

Dillenburg (1988), studying the external continental shelf and upper slope of the region adjacent to the La Plata palaeochannel noted the occurrence of pyroclastic material (volcanic glass), in the majority of samples analyzed. According to Etchichury \& Remiro (1960) and Urien (1967) the presence of volcanic glass is common in the sediments of the continental shelf and coastal plain of the region under the influence of the La Plata River (Northern Argentina and Uruguay). Etchichury \&
Remiro (1960) attributed the volcanic glass found in the estuary, on the continental shelf and surroundings of the La Plata River, to volcanic material from Andean eruptions and transported to the area by winds. It thus seems evident that this pyroclastic material was transported by the wind as far as the coastline at that time and redistributed by the fluvial and marine systems, confirming the influence of the La Plata River in the contribution and partial distribution of the sediments on the external continental shelf and the slope. According to Dillenburg (1988) the sedimentation of the external continental shelf and upper slope between Rio Grande and Chuí appears to have been under major influence of the fluvial system of the La Plata River.

Costa \& Ramos (1983), studying the surface sediments of the continental shelf of Rio Grande do Sul, observed the predominance of esmectite over illite, with an exception in the area of occurrence of the palaeo-valley of the La Plata River, where clay-mineral illite predominates. Urien (1967), studying the clayminerals of the estuary of the La Plata River, observed two discrete zones, one to the South with a predominance of esmectite and another on the Uruguayan coast with a predominance of illite. The data obtained by these authors bear out the influence of the La Plata River in the study area, transporting illite and enriching the sediments of the palaeo-channel.

Remus et al. (2008) describe the origin of the garnets present in the surface sediments of the Pelotas Basin as coming from the Rio Grande do Sul Shield, from rocks with a high degree of metamorphism, granulites, pelitic gneisses and charnockites. They mention that the drainage responsible for transporting these garnets is linked to the basin of the Uruguay River and La Plata River.

Based on the information described above, we favor the hypothesis that the depression observed on the continental shelf of the Southern region of Brazil is a palaeo-channel, mainly based on the mineralogical composition of its sediments which are related to the same La Plata River and Uruguay River heavy mineral assemblages. In this regard, we discard the hypothesis that the depression is a palaeo-lagoon. Other evidence is the enrichment of illite in the sediments of the palaeo-channel, in respect to esmectite which predominates in the area adjacent to the continental shelf of Rio Grande do Sul.

\section{DISCUSSION AND CONCLUSION}

According to Corrêa (1986, 1990) and Corrêa \& Toledo (1998), the sea-level was $120 \mathrm{~m}$ below its current level in the Rio Grande do Sul continental shelf at 17,500 years BP.

With the marine transgression, the flooding of the palaeodrainage generated estuaries and lagoons in the coastal areas, as 


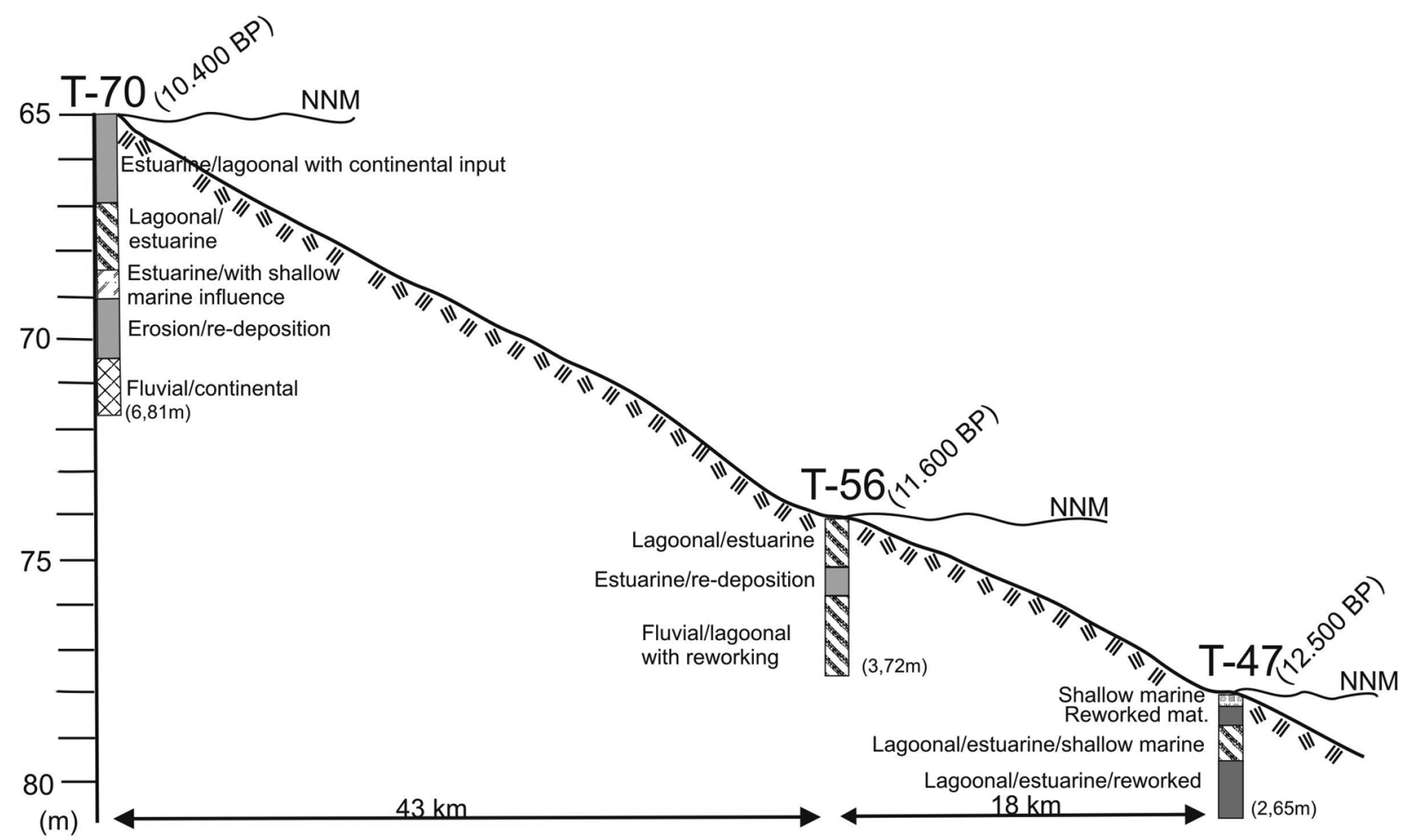

Figure 8 - Palaeo-evolutionary interpretation of the palaeo-channel of the La Plata River.

indicated by the palynological and sedimentary description of the cores analyzed in this work.

The 3D bathymetric model obtained with the available bathymetric data allowed a good representation of the geomorphology of the part of the La Plata palaeo-channel on the continental shelf of Rio Grande do Sul with its preferential direction from SW to NE.

In the description of core T-47 (depth of $78 \mathrm{~m}$ ), we observe from its base to the top, a gradation from a lagoonal/estuarine environment containing reworked costal sediments to a lagoonal/estuarine environment with restricted marine influence, and finally to an environment with open marine influence, showing its transgressive nature. Considering the water depths in comparison to the sea-level curve (Corrêa, 1996), the age of this interval is estimated as 12,500 years BP (Fig. 8).

In the process of the marine transgression, the palaeochannel drainage of the La Plata River was progressively drowned, as we can observe from the description of core T-56 (depth $74 \mathrm{~m}$ ) where, from base to top, there is a gradational change from a fluvial/lagoonal environment, followed by a small regressive gap, and subsequently fluvial/lagoon, and lagoon/estuarine environment, grading to open marine at the top. Comparing the depths with the sea-level curve of Corrêa (1996), we can attribute an age of some 11,600 years BP for this interval (Fig. 8).
Core T-70 (depth of $65 \mathrm{~m}$ ) from the Southern sector of the channel is characterized by a basal sedimentary unit deposited in a fresh water/continental environment grading to a unit with erosion/deposition under marine influence, followed by marine/estuarine and lagoonal/estuarine environments, and finally into estuarine/marine environment with continental influence. The top of the sequence is covered by muddy marine sediments. Comparing the depths with the sea-level curve of Corrêa (1996), this level may present an age of approximately 10,400 years BP, when soon afterwards the rate of sea-level rise decreases around the present water depth of $-60 \mathrm{~m}$, reworking the sediments and drowning the palaeo-channel in this region (Fig. 8).

Based on the sedimentological and palynological studies of the three geological cores analyzed from the continental shelf of Rio Grande do Sul, it is possible to characterize transgressive depositional episodes in the La Plata River palaeo-channel. The interpretation was feasible through the ecobathymetric records and palynological analyses of the sediments obtained from the cores collected in the palaeo-channel.

The palynological successions revealed marine environments grading to mixohaline, lagoonal and fresh water continental environments, from the northernmost to the southernmost locations of the channel. 
From the sedimentological point of view, the sedimentary cover is of fluvial/estuarine origin from the drainage of the La Plata provided during the last Pleistocene/Holocene deglaciation.

The presence of the La Plata River palaeo-channel on the Southern part of the continental shelf of Rio Grande do Sul has an influence on conditioning the directional flow of regional water masses on the continental shelf. According to Campos et al. (2009) these water masses end up reflecting in the production and distribution of marine organisms.

The data analyzed contain new information for understanding the sedimentary contribution and influence of the La Plata River on the south Brazilian continental shelf.

\section{ACKNOWLEDGMENTS}

The authors wish to thank the CNPq (processes no. 560661/2008, no. 500931/2007-0, no. 00437/2009-9, nо. 470915/2010-2, no. 471518/2010-7, no. 370274/2011-3, no. 300609/2013-2) and FAPERGS (processes no. 09510618, no. 11/0204-7) for the scholarships and assistance provided. We also thank Laboratory Technician Gilberto Silveira dos Santos and Laboratory Assistant Jonas Lawall dos Santos for conducting the sedimentary analyses, and the external reviewers for their critics and suggestions concerning the manuscript.

\section{REFERENCES}

ABREU JGN \& CALLIARI L. 2005. Paleocanais na plataforma continental interna do Rio Grande do Sul: Evidências de uma drenagem fluvial pretérita. Brazilian Journal of Geophysics, 23(2): 123-132.

ASMUS HE. 1981. Geologia das Bacias Marginais Atlânticas Mesozoicas-Cenozoicas do Brasil. In: Comitê Sudamericano del Jurásico y Cretácico: Cuencas sedimentarias del Jurásico y Cretácico de América del Sur, Buenos Aires, 1: 127-155.

AYUP-ZOUAIN RN. 1987. Intercâmbio sedimentar entre o rio de La Plata exterior e a plataforma continental adjacente. Revista Pesquisas, Instituto de Geociências, UFRGS, 19: 105-126.

BATTEN DJ. 1996. Palynofacies. In: JANSONIUS J \& McGREGOR DJ (Eds.). Palynology: Principles and Applications. AASP, Dallas, Texas, 1011-1064.

BERTELS A, KOTZIANS S, MADEIRA-FALCETTAM \& THIESEN Z. 1984. Notas preliminares sobre a micropaleontologia da plataforma e talude do Rio Grande do Sul. Notas Técnicas, CECO/UFRGS, 4: 27-32.

BRASIER MD. 1992. Microfossils. London, Chapman \& Hall, 193 pp.

CAMPOS PC, WEIGERT SC \& MADUREIRA LSP. 2009. Ecobatimetria e características acústicas do leito oceânico na região do canal do Albardão, Rio Grande do Sul, Brasil. Atlântica, FURG, 31(1): 5-23.
CHIOCCI F. 2001. Continental shelf morphoestratigraphic features due the last sea-level rise: certainties and uncertainties with examples of Mediterranean shelf. In: 1st Annual Conference of Continental Shelves during the last Glacial Cycles. Proceedings... IGCP Project 464. UNESCO. CD-ROM.

CONTI LA. 2009. Evidências da evolução dos sistemas de paleodrenagens na plataforma continental da região de São Sebastião (litoral norte do estado de São Paulo). Revista Brasileira de Geomorfologia, 10(2): 45-55.

CORDAZZO CV \& STÜRMER SL. 2007. Ocorrência de fungos micorrízicos arbusculares em Panicum racemosum (P. Beav.) Spreng (Poaceae) em dunas costeiras do extremo sul do Brasil. Atlântica, FURG, 29(1): 65-68.

CORRÊA ICS. 1986. Evidences of sea-level fluctuation in the Rio Grande do Sul Continental Shelf-Brazil. Quaternary of South America and Antarctic Peninsula, Holland, 4: 237-247.

CORRÊA ICS. 1987a. Sedimentos superficiais da plataforma e talude continental do Rio Grande do Sul. Revista Pesquisas, Instituto de Geociências, UFRGS, 19: 95-104.

CORRÊA ICS. 1987b. Plataforma continental do Rio Grande do Sul: síntese de conhecimentos. In: Simpósio sobre ecossistemas da costa sul e sudeste do Brasil, Cananéia-SP, 2: 50-73.

CORRÊA ICS. 1990. Analyse Morphostructurale et Évolution Paléogéographique de la plate-forme Continentale Atlantique Sud-Brésilienne (Rio Grande do Sul-Brésil). Bordeaux. Université de Bordeaux I, Doctorate Thesis. France. 314 pp.

CORRÊA ICS. 1996. Les variations du niveau de la mer durant les derniers 17.500 ans BP: exemple de la plate-forme continentale du Rio Grande do Sul-Brésil. Marine Geology, 130(1/2): 163-178.

CORRÊA ICS \& TOLDO Jr EE. 1998. The sea-level stabilization in the Rio Grande do Sul Continental Shelf, Brazil. Anais da Academia Brasileira de Ciências, 70(2): 213-219.

CORRÊA ICS, MARTINS LR, KETZER JM, ELIAS ARD \& MARTINS R. 1996. Evolução sedimentológica e paleogeográfica da plataforma continental sul e sudeste do Brasil. Notas Técnicas, CECO/UFRGS, 9: 51-61.

COSTA C \& RAMOS FT. 1983. Argilo-minerais na plataforma continental sul-brasileira do cabo Santa Marta ao Chuí. Revista Pesquisas, Instituto de Geociências, UFRGS, 15: 86-93.

DILLENBURG SR. 1988. Contribuição à evolução paleogeográfica quaternária da plataforma continental do Rio Grande do Sul. Master dissertation on Geosciences, UFRGS. 77 pp.

ETCHICHURY MC \& REMIRO JR. 1960. Muestras de fondo de la plataforma continental. Comprendida entre los paralelos $34^{\circ}$ y $36^{\circ} 30^{\prime}$ de latitud sur y los meridianos $53^{\circ} 10^{\prime}$ y $56^{\circ} 30^{\prime}$ de longitud oeste. Revista del Museo Argentino de Ciencias Naturales Bernardino Rivadavia, 4(4): 197-263. 
FAEGRI K \& IVERSEN J. 1975. Text-book of pollen analysis. Scientific Publications. Amsterdam, 295 pp.

FIGUEIREDO Jr AG \& MADUREIRA LSP. 2004. Topografia, composição, refletividade do substrato marinho e identificação das províncias sedimentares na região Sudeste-Sul do Brasil. Série Documentos REVIZEE Score Sul, 64 pp.

FOLK RL \& WARD WC. 1957. Brazos River bar: a study on the significance of grain size parameters. Journal of Sedimentary Petrology, 27(1): 3-26.

JANKOVSKÁV \& KOMÁREK J. 2000. Indicative value of Pediastrum and other coccal green algae in Palaeoecology. Folia Geobotanica, 35: 5982.

JARZEN DM \& ELSIK WC. 1986. Fungal palynomorphs recovered from recent river deposits, Luangwa Valley, Zambia. Palynology,10: 35-60.

KOWSMANN RO \& COSTA MPA. 1979. Sedimentação quaternária da margem continental brasileira e das áreas oceânicas adjacentes. Série Projeto REMAC (8), 55 pp.

KOWSMANN RO, COSTA MPA, VICALVI MA, COUTINHO MGN \& GAMBOA LAP. 1977. Modelo da sedimentação holocênica na plataforma continental sul-brasileira. In: Série Projeto REMAC - Evolução sedimentar holocênica da plataforma continental e do talude do sul do Brasil. Rio de Janeiro, Petrobras. CENPES. DINTEP, p. 7-26.

LABORDE JL. 1999. Sand deposits of the outer Rio de La Plata and adjacent continental shelf. In: MARTINS LR \& SANTANA CI (Eds.). Nonliving resources of the southern Brazilian coastal zone and continental margin. p. 80-91.

LOBO FJ, FERNÁNDEZ-SALAS I, MORENO JLS \& MALDONADO A. 2006. Shallow-water depositional bodies and sediment by-pass styles in a Mediterranean shelf fed by small rivers, northern Alboran Sea margin. Continental Shelf Research, 26: 2607-2628.

MARTINS LRS. 1978. Operação GEOMAR IV. Geologia Marinha. Diretoria de Hidrografia e Navegação. Rio de Janeiro. Boletim DG32-IV: 1-19.

MARTINS LRS. 1984. Modelo sedimentar do Cone de Rio Grande. Revista Pesquisas, Instituto de Geociências, UFRGS, 16: 91-189.

MARTINS LRS, MARTINS IR \& URIEN CM. 2003. Aspectos sedimentares da plataforma continental na área de influência do Rio de La Plata. Gravel, UFRGS, 1: 68-80.

MARTINS LRS, URIEN CM \& MARTINS IR. 2005. Gênese dos sedimentos da plataforma continental Atlântica entre o Rio Grande do Sul (Brasil) e Tierra del Fuego (Argentina). Gravel, UFRGS, 3: 85-102.

MEDEANIC S \& CORRÊA ICS. 2007. Silicoflagellate Dictyocha Ehrenberg from the middle Holocene sediments in the coastal plain of Rio Grande do Sul, Brazil. Revista Española de Micropaleontologia, 39(3): 227-239.
MEDEANIC S \& CORRÊA ICS. 2010. Climatic changes in the coastal plain of the Rio Grande do Sul state in the Holocene: palynomorph evidences. Pan-American Journal of Aquatic Sciences, 5(2): 287-297.

MEDEANIC S, CORRÊA ICS \& WESCHENFELDER J. 2007. Palinomorfos nos sedimentos de fundo da laguna dos Patos-RS: Aplicação nas reconstruções paleoambientais. Gravel, UFRGS, 5(2): 89-102.

MEDEANIC S, CORDAZZO CV, CORRÊA ICS \& MIRLEAN N. 2008. Os fitólitos em gramíneas de dunas do Extremo Sul do Brasil: Variabilidade morfológica e importância nas reconstruções paleoambientais costeiras. Gravel, UFRGS, 6(2): 1-14.

MEDEANIC S, CORDAZZO CV, CORRÊA ICS \& MIRLEAN N. 2009a. Notas sobre fitólitos em Androtrichum trigynum (Spr.) Pfeiffer no extremo sul do Brasil: Tipos morfológicos e uso nas paleoreconstruções costeiras. Gravel, UFRGS, 7(1): 31-36.

MEDEANIC S, TORGAN LC, CLEROT LCP \& SANTOS CB. 2009b. Holocene marine transgression in the coastal plain of Rio Grande do Sul, Brazil: palynomorph and diatom evidence. Journal of Coastal Research, 25(1): 224-233.

PANTIC N \& BAJRAKTAREVIC Z. 1988. "Nannoforaminifera" in palynological preparations and slides from Mesozoic and Tertiary deposits in Central and Southeast Europe. Revue de Paléobiologie, Benthos-86, 2(2): 953-959.

REMUS MVD, SOUZA RS, CUPERTINO JA, DE ROS LF, DANI N \& VIGNOL-LELARGE ML. 2008. Proveniência sedimentar: métodos e técnicas analíticas aplicadas. Revista Brasileira de Geociências, 38(2suplemento): 166-185.

RODRIGUES MAC \& CARVALHO MGP. 1980. Curvas paleoclimáticas com base em foraminíferos de testemunhos da plataforma sul-brasileira. Anais da Academia Brasileira de Ciências, Rio de Janeiro, 52(3): 617625.

TOMAZELLI L. 1978. Minerais Pesados da Plataforma Continental do Rio Grande do Sul. Acta Geológica Leopoldensia, São Leopoldo-RS, 2(5): 103-159.

TYSON R. 1995. Sedimentary Organic Matter. Chapman \& Hall, London. $615 \mathrm{pp}$.

URIEN CM. 1967. Los sedimentos modernos del Rio de La Plata exterior. Boletín del Servicio de Hidrografía Naval, Buenos Aires, 4(2): 113-213.

URIEN CM. 1970. Les rivages et le plateau continental de Sud du Brésil, de l'Uruguay et de l'Argentina. Quaternaria, Rome, 12: 57-69.

URIEN CM \& EWING M. 1974. Recent sediments and environment of Southern Brazil, Uruguay, Buenos Aires and Rio Negro continental shelf. In: BURK CA \& DRAKE CL (Eds.). The Geology of Continental Margins. Berlin, Springer, p. 157-177.

URIEN CM \& MARTINS LR. 1974. Sedimentos da plataforma continental sul-americana entre cabo Santa Marta (Brasil) e Terra do Fogo (Argentina) Parte 1: textura sedimentar e origem. In: Congresso Brasileiro de Geologia, 28., Porto Alegre. Proceedings... São Paulo, SBG, 3: 213-223. 
URIEN CM \& MARTINS LR. 1989. Southern Brazil, Uruguay and Argentina: Late Pleistocene events modeling a sequential stratigraphic analysis. In: International Symposium on Global Changes in South America during the Quaternary: past, present, future. ABEQUA Special Publication, São Paulo, 1: 197-208.

VAN GEEL B. 1976. Fossil spores of Zygnemataceae in ditches of a prehistoric settlement in Hoogkarspel (The Netherlands). Review of Palaeo- botany and Palynology, 22: 337-344.

VAN GEEL B \& VAN DER HAMMEN T. 1978. Zygnemataceae in Quaternary Colombian sediments. Review of Palaeobotany and Palynology, 25: $377-392$.

VAN VEEN FR. 1957. Microforaminifera. Micropalaeontology, 3(1): $74-74$.

Recebido em 20 junho, 2011 / Aceito em 07 janeiro, 2013

Received on June 20,2011 / Accepted on January 7, 2013

\section{NOTES ABOUT THE AUTHORS}

Iran Carlos Stalliviere Corrêa. Geologist (UFRGS/1973), Master in Geosciences (UFRGS/1979) and Doctor in Oceanology (University of Bordeaux I-France/1990). Researcher 1D at the CNPq, responsible for various projects in the area of Marine Geology and Sedimentology. Professor at the Department of Geodesics, since 1973, and at the Graduate Program of Geosciences at UFRGS since 1981. Director of the Centro de Estudos de Geologia Costeira e Oceânica (CECO/IG/UFRGS).

Svetlana Medeanic. (in memoriam) Geologist from the Moscow State University (1972), Master in Palaeontology and Stratigraphy from Moscow State University (1974) and Doctor in Palaeontology and Stratigraphy from Moscow State University (1981). Specialist in Cenozoic Palaeontology and Stratigraphy with emphasis on Palynology. Professor at the Oceanography Institute at FURG. Has developed palynological works in archeological sites from the Palaeolithic, Mesolithic and Neolithic in the SW of the Russian shelf. Has developed palynological studies on Quaternary sediments from the coastal plain of Rio Grande do Sul State, Brazil.

Jair Weschenfelder. Geologist (UFRGS/1993), Master in Geosciences (UFRGS/2005), and Doctor in Science (UFRGS/2009) and Professor of the Department of Geodesics at UFRGS since 1996, in the areas of topography, geodesics and cartography and at the Graduate Program of Geosciences at UFRGS since 2012. A researcher at the Centro de Estudos de Geologia Costeira e Oceânica (CECO/IG/UFRGS) developing studies in seismic-stratigraphy, geophysics, coastal and marine geology, costal evolution and palaeo-geography.

Elírio Ernestino Toldo Jr. Geologist (UFRGS/1981), Master in Geosciences (UFRGS/1989) and Doctor in Sciences (UFRGS/1994). Professor at the Department of Mineralogy and Petrology at UFRGS, responsible for the disciplines "Sedimentology l", "Methods of Sedimentology" and a collaborator in the discipline "Marine and Coastal Geology". Responsible for the graduate level disciplines "Physical Oceanography I" and "Coastal Processes". Researcher 1D at the CNPq. Has published various articles and chapters of books on coastal processes at Lagoa dos Patos and the coast of Rio Grande do Sul State, Brazil.

José Carlos Nunes. Technician from Parobé Technical School (1977), Technician in Hydrology (UFRGS/1979), certificates in Data Processing (UESTT/1982); Programming in Language C, Image Treatment Geo-informatics (INPE/1996). Participates in researchers at the Centro de Estudos de Geologia Costeira e Oceânica (CECO/IG/UFRGS).

Ricardo Baitelli. Geologist (UNISINOS/1981), Master in Geosciences (UFRGS/1992) and Doctor in Sciences (UFRGS/2012). Professor at the Department of Geodesics at UFRGS, since 1993, and Researcher at the Centro de Estudos de Geologia Costeira e Oceânica (CECO/IG/UFRGS) developing studies in coastal and marine geology and palaeo-geography and evolution of the coastal region of Rio Grande do Sul State, Brazil. 